\title{
Ukrainians battle escalating HIV epidemic
}

Cite as: CMAJ 2017 July 4;189:E901-2. doi: 10.1503/cmaj.1095410

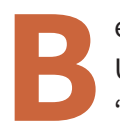

efore the war with Russia, Ukraine's fight against HIV was a "success story," says Jacek Tymszko, country director for the Joint United Nations Programme on HIV/AIDS (UNAIDS).

Ukraine has long had one of the highest HIV infection rates in Europe, with a prevalence as high as $1 \%$ in the mid2000 s, according to UNAIDS. But before the war with Russia began in 2014, the country looked like it was turning a corner. In 2012, rates of new infection declined for the first time, from more than 17300 new cases in 2011 to 16847 a year later. Overall, prevalence was pegged at $0.8 \%$. This progress was likely a result of investments in antiretroviral treatment and, unlike in Russia, the use of opioid substitution therapy for intravenous drug users.

Now HIV infection rates are again rising because of the war, and its attendant political and economic instability. According to the government's most recent official statistics, there are 220000 people living with HIV/AIDS in Ukraine, a prevalence rate of $0.9 \%$. The number of new officially registered cases increased by nearly $8 \%$ in 2016 , while the mortality rate related to AIDS increased 7\%; most (52\%) were due to tuberculosis.

"When the conflict started, HIV totally disappeared from the agenda," says Tymszko.

However, the situation in 2017 could have been much worse. The largest international donor to Ukraine's HIV/AIDS fight, the Global Fund to Fight AIDS, TB and Malaria, has spent more than US\$500-million in the Ukraine since 2003. "It was initially discussed that this grant [2017] would be the last for Ukraine," said Dr. Natalia Nizova, head of the Ukrainian government's Public Health Center. But the global fund took the "unprecedented

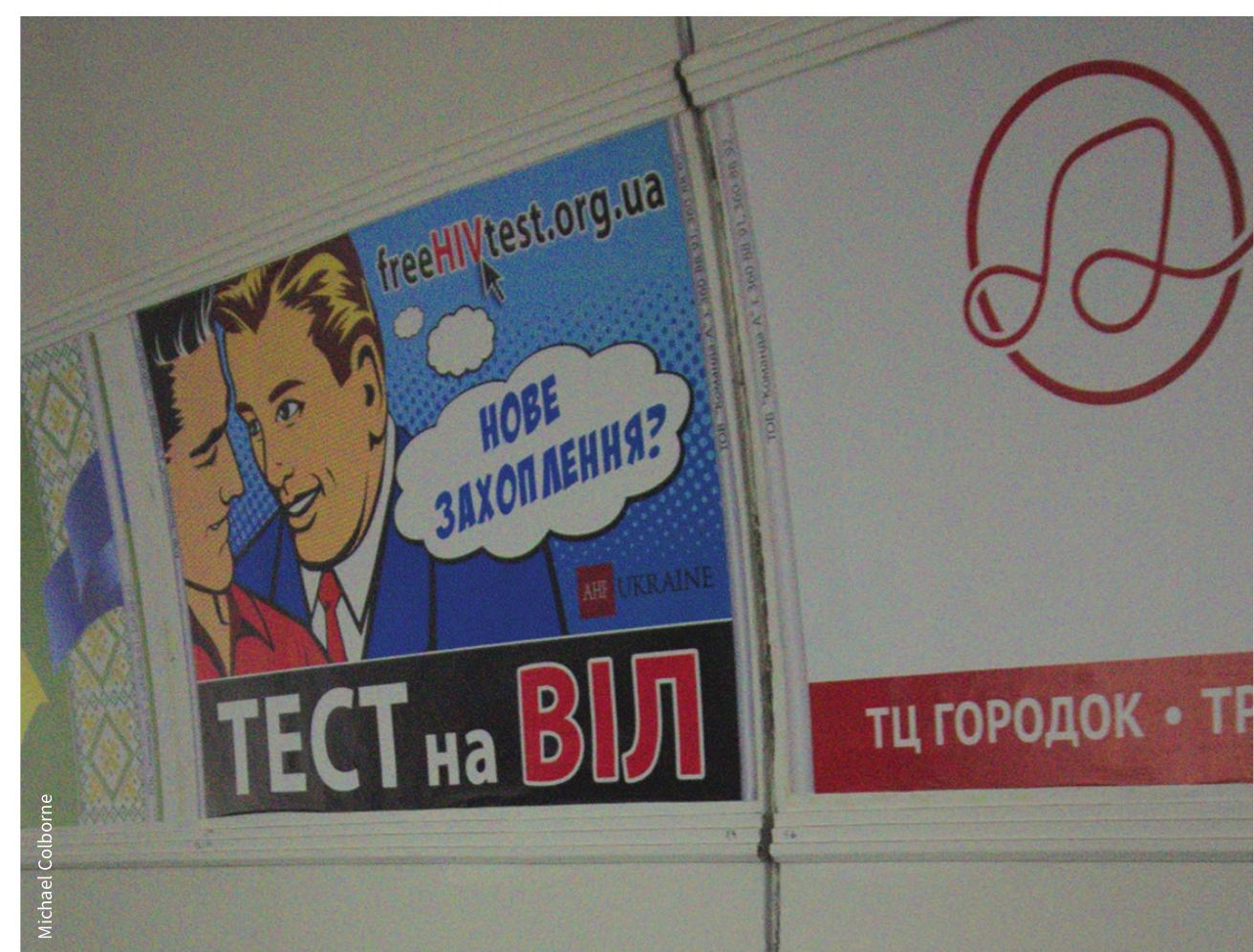

Subway ads for free HIV testing have prompted complaints about the promotion of "non-traditional sexual orientation."

decision" to continue financing Ukraine with a US\$120-million grant until 2020, with the expectation that the Ukrainian government continue to increase its own spend on HIV/AIDS and fully fund it from 2021 onward, she said.

That expectation has led activists to step up efforts to get HIV/AIDS back on the agenda. Dmytro Sherembey heads up the All-Ukrainian Network of People Living With HIV/AIDS. He says that intense pressure from his and other organizations has helped convince the Ukrainian government to increase spending on HIV prevention. Alongside overall health spending which was cut by more than $40 \%$ in 2015 - HIV prevention programing was slashed by $42 \%$ over 2014 and 2015. This year, the Ukrainian government increased its bud- get to purchase drugs for HIV patients by US\$80 million.

At the Elena Pinchuk ANTIAIDS Foundation, a non-governmental organization started up by the daughter of Ukraine's second president Leonid Kuchma, Olga Rudneva stresses the importance of this spending, particularly the Ukrainian government's commitment of US\$500 000 to fully fund opioid substitution therapy throughout the country in 2017.

"That's huge progress," she says. "Five years ago, that wouldn't even have been considered."

The next few years - the last with major global fund support - are Ukraine's "last window of opportunity" to turn the corner against the HIV epidemic, says Nizova. She says it will not be easy, but believes the 
country's experience and the existing collaboration between government and nongovernmental agencies, as well as examples of best practices from its pre-2014 successes, mean that Ukraine may well be able to complete the transition.

"We're more optimistic than you," she says.
On another front, activists are also fighting the prevailing stigma attached to HIV in Ukraine. Since November, the AIDS Healthcare Foundation (AHF) has placed more than a hundred advertisements promoting free HIV tests in metro stations throughout Kyiv. One of these ads featured two men together and the Kyiv metro company has since received complaints about the advertisements, calling them promotion of "nontraditional sexual orientation."

"Some of the ads were even ripped down in some metro stations," says AHF spokesperson Natalia Ruda.

Michael Colborne, Kyiv, Ukraine 